\title{
PENGARUH PEMANFAATAN DAUN UBI JALAR (Ipomea batatas $L$ ) TERHADAP PERFORMANS TERNAK KELINCI
}

\author{
Meysi B Sampul, B. Tulung*, J. F. Umboh, S. A. E. Moningkey \\ Fakultas Peternakan Universitas Sam Ratulangi Manado, 95115.
}

\begin{abstract}
ABSTRAK
Penelitian ini bertujuan untuk mengkaji sejauh mana pemanfaatan daun ubi jalar terhadap performans ternak kelinci meliputi konsumsi pakan, pertambahan bobot badan dan konversi pakan. Penelitian menggunakan 20 ekor ternak kelinci peranakan New Zealan White umur 4-6 minggu dengan bobot badan awal 400-600 g/ekor. Rancangan penelitian ini menggunakan Rancangan Acak Lengkap dengan 5 perlakuan dan 4 ulangan dengan tingkat pemberian daun ubi jalar dalam pakan yaitu R0 : 0\%, R1 : 25\%, R2 : 50\%, R3 : 75\%, R4 : 100\%. Data diuji dengan analisis ragam, apabila terdapat pengaruh yang nyata dilakukan uji lanjut menggunakan Uji Beda Nyata Jujur (BNJ). Hasil penelitian menunjukkan bahwa pemberian daun ubi jalar dalam pakan ternak kelinci berbeda nyata $(\mathrm{P}<0,05)$ terhadap performans ternak kelinci meliputi konsumsi pakan, pertambahan bobot badan dan konversi pakan.
\end{abstract}

Kata kunci: Kelinci, Daun Ubi Jalar, Konsumsi Pakan, Pertambahan Bobot Badan, Konversi Pakan

\section{ABSTRACT \\ THE EFFECT OF SWEET POTATO LEAVES (IPOMEA BATATAS) ON THE PERFORMANCE OF RABBIT. This study aims to examine}

*Korespondensi (Corresponding author) Email: bernat.tulung@gmail.com the extent to which the use of sweet potato leaves on the performance of rabbit cattle include feed consumption, body weight gain and feed conversion. The study used 20 rabbits of New Zealand White rabbit aged 4-6 weeks with initial body weight 400-600 g / tail. The design of this study using Completely Randomized Design with 5 treatments and 4 replications with the level of sweet potato leaves in the feed that is R0: $0 \%, \mathrm{R} 1: 25 \%, \mathrm{R} 2: 50 \%, \mathrm{R} 3$ : $75 \%, \mathrm{R} 4: 100 \%$. The data were tested by multiform analysis, if there is a real effect of further test using Test of Honest Significance Difference (HSD). The results showed that the provision of sweet potato leaves in rabbit fodder was significantly different $(\mathrm{P}<0.05)$ on rabbit performance including feed consumption, body weight gain and feed conversion`

Keywords: Rabbit, Sweet Potato Leaf, Feed Consumption, Weight Gain, Feed Conversion.

\section{PENDAHULUAN}

Di Indonesia ternak kelinci mempunyai kemampuan kompetitif untuk bersaing dengan sumber daging ternak lain dalam memenuhi kebutuhan gizi dan merupakan alternatif penyedia daging yang perlu dipertimbangkan di masa yang akan datang. Daging kelinci merupakan salah satu daging yang berkualitas baik dan 
layak dikonsumsi (Dwiyanto et al., 1985). Kelinci memiliki kemampuan bilogis yang tinggi, selang beranak yang pendek, mampu beranak banyak, dapat hidup dan berkembang dengan baik, populasi kelinci di indonesia tahun 2017 mencapai 1.237.762 ekor (BPS, 2017). Menurut Mastika (1991), salah satu alternatif untuk penyediaan pakan yang murah dan kompetitif adalah melalui pemanfaatan limbah.

Masalah yang dihadapi oleh peternak adalah biaya pakan yang tinggi. Salah satu upaya untuk menekan biaya pakan yaitu mencari bahan pakan alternatif berasal dari limbah pertanian (Moningkey et al., 2016). Kelinci dapat memanfaatkan hijauan dan produk limbah dengan efisien dan mencerna hijauan dengan kandungan serat kasar yang tinggi. Pertumbuhan yang optimal dipengaruhi oleh kualitas dan kuantitas pakan yang dikonsumsi. Kelinci pada masa pertumbuhan membutuhkan Digestible energy (DE) $2500 \mathrm{kkal} / \mathrm{kg}$, TDN $65 \%$, serat kasar 10-12\%, protein kasar 16\% dan lemak 2\% (NRC, 1977). Untuk produksi yang maksimal diperlukan pakan yang berkualitas berupa hijauan dan konsentrat, dan untuk menekan biaya pakan dengan cara memanfaatkan limbah pertanian.

Daun Ubi jalar (ipomea batatas) merupakan limbah pertanian yang sangat cocok untuk digunakan sebagai pakan dan salah satu komoditas untuk penyediaan pakan kelinci yang cukup bergizi, kuantitasnya cukup banyak dan harganya relatif murah, serta kandungan nutrisi yang baik untuk ternak. Bagian umbi ubi jalar merupakan bahan pangan untuk manusia sedangkan daunnya yang adalah sisa-sisa pertanian sudah digunakan untuk ternak sapi, kambing, domba dan unggas (Heuze et al., 2015). Potensi produksi ubi jalar tahun 2009 telah mencapai 2.590.929 ton. Daun ubi jalar dapat dijadikan bahan pakan sumber protein karena mengandung protein kasar 25-29\%. Daun ubi jalar memiliki faktor pembatas yaitu adanya suatu zat anti nutrisi (Tanin) dalam daun.

\section{MATERI DAN METODE PENELITIAN}

Penelitian ini dilaksanakan pada tanggal 9 Oktober 2017 sampai dengan 17 November 2017 dengan periode adaptasi dalam pelaksanaan penelitian ini selama 7 hari dan koleksi data selama 32 hari. Penelitian ini dilaksanakan di laboratorium Lapang Jurusan Nutrisi dan Makanan Ternak Fakultas Peternakan Universitas Sam Ratulangi Manado. Kelinci yang digunakan adalah kelinci lokal dengan bobot awal 400-600g. Kandang yang digunakan kandang metabolik, tiap kandang diisi 1 ternak dilengkapi dengan tempat pakan dan minum. Bahan pakan 
penyusun ransum percobaan terdiri dari daun ubi jalar, jagung kuning, tepung kedele, bungkil kelapa, dedak halus.

Penelitian ini menggunakan Rancangan Acak Lengkap (RAL) dengan 5 perlakuan dan 4 ulangan. Perlakuan yang Pakan diberikan dalam bentuk pellet secara ad libitum. Pemberian pakan diberikan adalah: R0 (Daun ubi jalar 0\% + Konsentrat 100\%), R1 (Daun ubi jalar 25\% + Konsentrat 75\%), R2 (Daun ubi jalar 50\% + Konsentrat 50\%), R3 (Daun ubi jalar $75 \%$ + Konsentrat 25\%), R4 (Daun ubi jalar 100\% + Konsentrat 0\%) dimulai dari masa adaptasi selama 7 hari dan koleksi data selama 32 hari.

Tabel 1. Kandungan Zat Makanan Bahan Pakan

\begin{tabular}{lllllll}
\hline Bahan pakan & $\mathrm{PK}(\%)$ & $\mathrm{SK}(\%)$ & $\mathrm{LK}(\%)$ & $\mathrm{Ca}(\%)$ & $\mathrm{P}(\%)$ & $\begin{array}{l}\mathrm{EM}(\mathrm{Kkal} \\
/ \mathrm{kg})\end{array}$ \\
\hline Jagung kuning & 9,42 & 2,15 & 5,17 & 0,22 & 0,6 & 2985 \\
Dedak halus & 13,44 & 6,3 & 6,07 & 0,19 & 0,73 & 2695,5 \\
Tepung kedelai & 40,38 & 6,56 & 9,91 & 0,24 & 0,88 & 2540 \\
Bungkil kelapa & 24,74 & 9,36 & 15,02 & 0,11 & 0,47 & 3279,7 \\
Daun ubi jalar & 16,72 & 25,81 & 3,16 & 1,09 & 0,42 & 3581 \\
\hline
\end{tabular}

Tabel 2. Komposisi ransum dasar (konsentrat)

\begin{tabular}{lll}
\hline Ransum & $\%$ & Jumlah $(\mathrm{Kg})$ \\
\hline Jagung kuning & 40 & 7,680 \\
Dedak halus & 40 & 7,680 \\
Tepung kedelai & 10 & 1,920 \\
Bungkil kelapa & 10 & 1,920 \\
\hline Total & 100 & 19,200 \\
\hline
\end{tabular}

Tabel 3. Kandungan zat makanan ransum perlakuan

\begin{tabular}{lccccc}
\hline & $\mathrm{R} 0$ & $\mathrm{R} 1$ & $\mathrm{R} 2$ & $\mathrm{R} 3$ & $\mathrm{R} 4$ \\
\cline { 2 - 6 } Konsentrat (\%) & 100 & 75 & 50 & 25 & 0 \\
Daun ubi jalar (\%) & 0 & 25 & 50 & 75 & 100 \\
\hline Ransum Perlakuan & & & & & \\
Protein Kasar (\%) & 15,656 & 15,922 & 16,188 & 16,454 & 16,72 \\
Lemak Kasar (\%) & 6,989 & 6,989 & 5,0745 & 4,11725 & 3,16 \\
Serat Kasar (\%) & 4,972 & 10,1815 & 15,391 & 20,6005 & 25,81 \\
Kalsium (\%) & 0,199 & 0,42175 & 0,6445 & 0,86725 & 1,09 \\
Pospor (\%) & 0,637 & 0,58275 & 0,5285 & 0,47425 & 0,42 \\
Energi Metabolis (Kkal/Kg) & 1779,57 & 2229,928 & 2680,285 & 3130,643 & 3581 \\
\hline
\end{tabular}


Variabel yang diukur :

1. Konsumsi pakan (gram/ekor/hari) Konsumsi pakan, diukur berdasarkan selisih dari jumlah pemberian pakan dan jumlah sisa pakan per harinya.

2. Pertambahan berat badan (g/ekor) Pertambahan bobot badan, diukur berdasarkan selisih berat badan akhir dan berat badan awal.

3. Konversi pakan

Nilai konversi pakan diperoleh dari pembagian antara jumlah pakan yang dikonsumsi dengan pertambahan bobot badan selama penelitian

\section{HASIL DAN PEMBAHASAN}

Rataan konsumsi pakan (g.ekor ${ }^{1}$.hari ${ }^{-1}$ ), pertambahan bobot badan (g.ekor ${ }^{-}$ ${ }^{1}$.hari ${ }^{-1}$ ), dan konversi pakan (g.ekor ${ }^{-1}$.hari ${ }^{-}$ 1) masing-masing perlakuan selama penelitian disajikan dalam Tabel 1.

\section{Pengaruh perlakuan terhadap Konsumsi pakan}

Hasil analisis varians pengaruh perlakuan terhadap konsumsi pakan menunjukkan berbeda nyata $(\mathrm{P}<0,005)$. Data hasil penelitian (Tabel 1) menunjukkan bahwa semakin tinggi penggunaan daun ubi jalar dalam pakan, semakin tinggi konsumsi pakan ternak kelinci dalam penelitian ini. Menurut Muslih et al. (2005) bahwa salah satu faktor yang mempengaruhi konsumsi pakan adalah palatabilitas. Pada penelitian perlakuan R3 menunjukkan konsumsi yang lebih tinggi dari perlakuan yang lainnya. Hasil analisis statistik menunjukkan bahwa perlakuan memberikan pengaruh yang berbeda nyata $(\mathrm{P}<0,05)$ terhadap konsumsi pakan. Data hasil penelitian (Tabel 1) menunjukkan bahwa semakin tinggi penggunaan daun ubi jalar dalam ransum, semakin tinggi pula konsumsi pakan ternak kelinci dalam penelitian ini. Peningkatan konsumsi.

Tabel 4. Rataan konsumsi pakan, pertambahan bobot badan, dan konversi pakan kelinci lokal selama penelitian

\begin{tabular}{lccccc}
\hline \multicolumn{1}{c}{ Variabel } & R0 & R1 & R2 & R3 & R4 \\
\hline Konsumsi Pakan & $39,85^{\mathrm{a}}$ & $38,5^{\mathrm{a}}$ & $40,3^{\mathrm{ab}}$ & $45,7^{\mathrm{c}}$ & $43,5^{\mathrm{b}}$ \\
Pertambahan Bobot Badan & $11,80^{\mathrm{a}}$ & $11,20^{\mathrm{a}}$ & $13,10^{\mathrm{ab}}$ & $15,57^{\mathrm{c}}$ & $14,73^{\mathrm{b}}$ \\
Konversi Pakan & $3,39^{\mathrm{b}}$ & $3,44^{\mathrm{c}}$ & $3,07^{\mathrm{ab}}$ & $2,93^{\mathrm{a}}$ & $2,96^{\mathrm{a}}$ \\
\hline
\end{tabular}

Keterangan: superskrip yang berbeda pada baris yang sama menunjukkan perbedaan nyata $(\mathrm{P}<0,05)$ 
pakan ternyata hanya sampai pada perlakuan R3 (penggunaan pelet konsentrat $25 \%+$ daun ubi jalar $75 \%$ ) dalam pakan. Polii (2015) menambahkan bahwa pakan yang diberikan dalam bentuk pellet mempengaruhi konsumsi pakan. Ternak kelinci akan mengkonsumsi pakan lebih banyak apabila pakan dalam bentuk pellet.

\section{Pengaruh perlakuan Pertambahan Berat Badan}

terhadap

Hasil analisis

statistik menunjukkan bahwa pertambahan bobot badan ternak kelinci dalam penelitian semakin meningkat secara nyata $(\mathrm{P}<0,05)$. Pertambahan berat badan ternak kelinci paling tinggi terdapat pada perlakuan R3 yaitu 15,57 g.ekor ${ }^{-1}$.hari ${ }^{-1}$; sedangkan pertambahan berat badan ternak kelinci paling rendah yaitu pada perlakuan R1 yaitu 11,20 g.ekor ${ }^{-1}$.hari ${ }^{-1}$. Pertambahan bobot badan ini masih sesuai dengan pernyataan Lukehfar dan Chekee (1990), bahwa pertumbuhan kelinci pada daerah tropis berkisar antara 10- 20 g.ekor ${ }^{-1}$ hari $^{-1}$.

Angka pertambahan berat badan ternak kelinci dalam penelitian ini mengikuti pola konsumsi pakan yaitu bahwa peningkatan konsumsi pakan dan pertambahan bobot badan terjadi sampai pada perlakuan R3, Menurut Marai et al. (2002) pertambahan bobot badan ternak dipengaruhi oleh tingkat konsumsi pakan dan faktor suhu lingkungan. Jadi pola konsumsi pakan akan menentukan pola pertambahan berat badan ternak kelinci. Kartadisastra (1997) menyatakan bahwa bobot badan ternak berbanding lurus dengan tingkat konsumsi pakannya

\section{Pengaruh perlakuan terhadap Konversi pakan}

Hasil analisis statistik menunjukkan bahwa perlakuan penggunaan daun ubi jalar dalam pakan kelinci dalam penelitian ini memberikan pengaruh yang berbeda nyata $(\mathrm{P}<0.05)$ terhadap konversi pakan. Rataan konversi pakan ternak kelinci pada penelitian ini berkisar antara 2,93 - 3,44. Angka konversi pakan dalam penelitian ini masih berada pada kisaran angka konversi pakan ternak kelinci menurut beberapa sumber yang ada. Mas'ud et al. (2015) melaporkan hasil penelitian yang menyatakan bahwa rataan konversi pakan ternak kelinci umur 2-3 bulan berkisar antara $2.83-6.25$. Sedangkan Wuysang et al. (2015) melaporkan angka konversi pakan pada ternak kelinci berumur 3,5 - 4,5 bulan berkisar 3.53- 3.80. Ternyata juga bahwa konversi pakan ternak kelinci dalam penelitian ini mengikuti pola konsumsi pakan dan pertambahan berat badan.

\section{KESIMPULAN}


Penggunaan daun ubi jalar dengan level $75 \%$ + konsentrat dengan level $25 \%$ dalam ransum dan diberikan dalam bentuk pellet memberikan hasil terbaik terhadap performans ternak kelinci.

\section{DAFTAR PUSTAKA}

Badan Pusat Statistik. 2017. Statistik Peternakan dan Kesehatan Hewan.

Dwiyanto, K., R. Sunarlin, dan P. Sitorus. 1985. Pengaruh persilangan terhadap karkas dan preferensi daging kelinci. Jurnal Ilmu dan Peternakan 1 (10): 427- 430

Heuze, V, Tran G, Hassoun P. 2015. Sweet Potato (ipomea batatas L) Forage Feedipedia. A programme by INRA., CIRAD, AFZ and FAO.

Kartadisastra, H. R., 1997. Ternak Kelinci Teknologi Pascapanen. Kanisius. Yogyakarta

Lukefahr, S. D dan P. R. Cheeke. 1990. Rabbit project planning strategies for developing countries (2): Research Aplication. Livestock Research for Rural Development. Vol.2 (2)

Marai, I. F. M., A.A.M. Habeeb, A.E. Gad. 2002. Rabbits' productive, reproductive and physiological performance traits as affected by heat stress: a review. Livest. Prod. Sci. 78, 71-90

Moningkey, S., M, Junus, O. Sjofjan, E. Widodo. 2016. Nutritive value evaluation on rumen content ang sludge fermented with
Cellulomonas Sp. as rabbit feed. International Journal of Cemtech Research Vol 09 (4) pp. 650-656.

Mas'ud, C. S., Y.R.L Tulung, J. Umboh, C.A Rahasia. 2015. Pengaruh pemberian beberapa jenis hijauan terhadap performans ternak kelinci. Jurnal Zootek Vol. 35(2): 289-94.

Mastika, I.M. 1991. Potensi Limbah Pertanian dan Industri Pertanian serta Pemanfaatannya untuk Makanan Ternak. Makalah Pengukuhan Guru Besar Ilmu Makanan Ternak Pada Fakultas Peternakan UNUD-Denpasar.

Muslih, D., I.W. Pasek dan Rosuartini. 2005. Pemanfaatan Tanaman (Galinsoga parviflora) Sebagai Bahan pakan Hijauan Bagi Kelinci.

NRC.1977. Nutrien Requirement of Rabbit. 2nd revised edition. National Academy of Sciences, Washington D.C. p 10.

Polii, P., K. Maaruf, Y. Kowel, H. Liwe. 2015. Pengaruh penambahan zat aditif (enzim dan asam organik) dengan protein tinggi dan rendah pada pakan berbasis dedak terhadap performan kelinci. Jurnal Zootek Vol. 35(2): 280-288

Wuysang, S., C. Rahasia, J. Umboh, Y. L. R. Tulung. 2017. Pengaruh penggunaan molases sebagai sumber energi pakan penguat dalam ransum terhadap pertumbuhan ternak kelinci. Jurnal Zootek 37(1): 149 - 155. 